\title{
Modeling CALL programs in EFL Flipped Classrooms to Enhance Achievement and Language Learning Attitude
}

\author{
Dr. Ayman Mohamed El-Esery \\ Lecturer of English Language \\ King Marriott Higher Institutes, Alex., Egypt \\ Dr. Nagat Ali Radwan \\ TEFL Ph.D.
}

\section{Abstract:}

omputer software has been widely used for
teaching English language in flipped classrooms.
The present study supplied a practical example of integrating Computer-Assisted language Learning (CALL) programs in English courses to flip the teaching process. The kind of CALL integration addressed in this study has allowed much more flexibility in delivering instruction to diverse groups of English learners or at best, to implement individualized instruction. Examples of modeling CALL programs in teaching listening, pronunciation, reading, writing, and vocabulary were implemented in this study. Sixty students (30 control group and 30 experimental group) studying at King Marriott Higher Institute for computer participated in this study. The control group studied through the regular non-flipped classroom while the experimental group studied through implementing CALL programs to flip the classroom. Following the Quasi experimental pre-post design the study was conducted during the first semester of the academic year 2016-2017. The results of the study showed that CALL programs in flipped classrooms have improved the students' language learning attitude and averaged examination scores to a statistically significant extent.

Key words: CALL, flipped classroom, attitude, individualized instruction.

\section{Background:}

\section{Introduction to call:}

What is call?

The acronym CALL represents a term that stands for Computer-Assisted Language Learning. It refers to 
manipulating computers in language teaching and learning. Traditionally, it is used as a means of teaching and assessing particular language items. Following the traditional CALL process, the learners are first introduced a rule and different examples, then, they practice varied exercises to test their knowledge of the rule and finally, the computer gives appropriate feedback and awards marks in records to be later checked by the teacher.

Levy and Hubbard (2005) define CALL as the field that is concerned with how the computer mediates between the language learner and language learning objectives (figure 1).

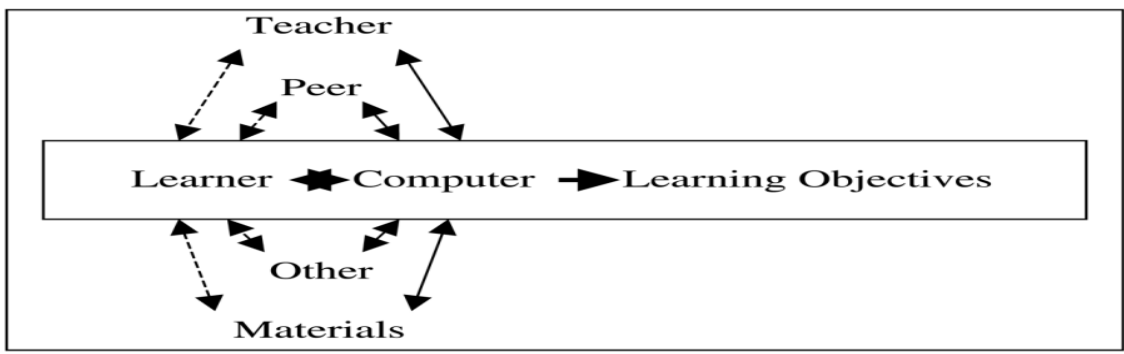

Figure 1. Levy and Hubbard's 2005 conceptualization of CALL

Levy (1997, p. 1) defines Computer-assisted Language Learning (CALL) as The search for and the study of computer applications in language teaching and learning. Beatty (2003, p. 7) gives a broad definition of what may go on in computerassisted language learning (CALL), Beatty gives a definition of CALL that accommodates its changing nature that is any process in which a learner uses a computer and, as a result, improves his or her language. Furthermore, CALL includes issues of material, design, technologies, pedagogical theories and of instruction modes. CALL materials include those which are mainly made for language learning and those which adapt the existing computerbased materials, e.g. video and other materials (Beatty, 2003, pp. 7-8).

\section{The History of CALL:}

For more than three decades, computers have been used in language teaching. Three main stages represent the history 
of CALL: Behaviouristic CALL, Communicative CALL and Integrative CALL (Warschauer \& Healey, 1998). Each stage corresponds to a certain pedagogical approach.

\section{Behaviouristic CALL:}

Influenced by audio-lingual teaching method, Behaviouristic CALL was emerged in the late 1960s and used widely in the 1970s. This stage was characterized by using repetitive language drills, known as drill-and practice. The computer represented a mechanical tutor that never allowed students to work individually, which in turn inhibited motivation. It also implied using extensive drills, grammatical explanations and translation (Warschauer \& Healey, 1998).

\section{Communicative CALL:}

The Communicative CALL initiated in the 1980s after rejecting the behavioristic approach to language teaching theoretically and pedagogically. At this time, personal computers were paving the way for students to work individually at schools. Corresponded to cognitive theories, Communicative CALL considered learning as a process of discovery, expression and development. Advocates of Communicative CALL debated that computer based activities should focus more on using communication forms. Furthermore, software including simulations and text reconstruction program was widely used and developed in this period. Therefore, Communicative CALL focused on what the students did with each other while working at the computer rather than what they did with the computer.

\section{Interactive CALL:}

Interactive CALL replaced communicative CALL which began to be criticized by the 1990s. Thus, teachers used more social and learner-centered methods in a response to new second language acquisition theories and socio-cognitive trends. Language learning in authentic social contexts was emphasized at this time. Content-based project-based and task-based approaches were applied to integrate learners 
in authentic environments, and to integrate and use various skills of language learning. In such integrative approaches, learners try to use a variety of technological tools and progress a continuing process of language learning instead visiting the computer lab once a week for conducting separated exercises.

\section{Types of CALL Programs:}

Davies, Hewer, Rendall, and Walker, (2004) divide CALL programs into:

- Specific CALL software: They are specific language learning programs designed to develop, facilitate the language learning process, like language learning CDs, language learning websites and quizzes.

- Generic software: They are general computer software designed for general purposes, like word-processors, presentation software, and spreadsheet, that can be used in language learning.

- Web-based language programs: They are online language learning programs like concordancers, online dictionaries, online encyclopedias, news/magazine sites, etc.

- Computer-mediated communication (CMC): programs for online oral and written communication like email programs, online asynchronous and synchronous chat, discussion forum, etc.

Warschauer (1996) divides CALL programs and applications into two main categories; computer as tutor programs and computer as tool programs. Computer as a tutor refers to CALL programs designed for teaching grammar, listening, pronunciation, reading, text reconstruction, vocabulary and writing. Computer as a tool refers to the most common use of a computer as a tool, and probably the usual use of computer programs for language learning, as word processing programs, grammar checkers, concordancers and collaborative writing.

\section{Advantages of computer in language teaching and learning:}

Teaching and learning technologies become one of the most effective areas in the educational system, especially in 
language learning (Reinders and Thomas, 2012). Today the number of teachers and students using computers and the Internet to teach/learn a second language has increased due to the technology advances (Han, 2008). In order to analyze the advantage of using computer in language learning, Li-Yun Lu and Tang (1996) divide the advantages into three types: the inherent nature of the computer; The benefit of the teacher; the benefit of the learner.

\section{The inherent nature of the computer:}

The computer can handle a much wider range of activities, and much more powerfully, than other technological aids. It offers a two-way learning session with the student. The computer can „assess" the student"s response. It can also display messages, take the student through subsequent attempts at a question, and even take the student to a different section of package, depending on the nature of the response.

\section{The benefit of the teacher:}

The computer presents several aspects of particular promise. Prominent among these is its versatility in handling different kinds of material. For example, the simplest is the oneway presentation of information, in the form of text, graphics, audio and video. Also, the computer can handle question-andanswer routines, simulated „dialogues", hypothesis testing, and many other types of exercises.

\section{The benefit of the learner:}

The computer also offers many advantages for the learner. "Access" is one of the benefits. The computer offers the student the choice of when to study particular topics and how long to spend on them. The flexibility makes many educational courses accessible to students who would otherwise have no chance to take them. It is not a dream to make the distance teaching. Many computers can be linked by telephone on special landlines. Alternatively, teachers can send tapes or discs of their materials through the post. Whatever the factors of time and distance, the computer retains its potential for personalized instruction. There 
is no "low attention" period as the student waits for his or her turn to come round in class. On the contrary, each student has the computer"s full attention and can work at the speed best suited to the individual.

\section{Flipped Classrooms:}

\section{What is a flipped classroom?}

The flipped classroom is a recent model of pedagogy in which the regular lecture and assignment elements of a course are reversed. In other words, activities that have traditionally taken place inside the classroom now take place outside the classroom and vice versa. For instance, instead of having lectures during sessions at university, students gather the information largely outside of sessions, by reading, watching videos and listening to podcasts or other audio format (Centre for Academic Development and Quality, 2016). Tucker (2012) adds there is more than one model for flipping the classroom, the core idea is to flip the regular instructional approach: with the help of teacher-created videos and interactive lessons, instruction that used to take place in class is now accessed at home, in advance of class. The classroom becomes a place to deal with problems, advance concepts, and to engage in collaborative and active learning.

In contrast to the lecture format, in flipped classrooms the role of the lecturer changes from being a presenter of content to a learning coach. Bergmann, Overmyer and Willie (2011) state that the lecturer is no longer the "sage on the stage" but the "guide on the side". Students become active learners instead of relying on the lecturer as the disseminator of knowledge.

\section{Advantages of the flipped classrooms:}

Flipped classrooms have may learning advantages related to sustainable learning, engagement and interaction. Bergmann, Overmeyer and Willie (2011) include several advantages for the "Flipped" classroom:

1. lifelong learning: learners depend on CALL programs to learn the content before coming to classrooms. Such method of acquiring knowledge, is a lifelong learning skill. 
2. Material engagement: in classroom learners complete different active learning exercises that reflect the applications, implications and controversies associated with the material. This engagement highlights the importance of the material in the learners' everyday lives and helps them relate to the topics.

3. interaction between learners and faculty: class periods are specified to interactions among the learners. This strategy shifts the focus of learners from the front of the classroom. The flipped classroom moves the faculty teacher from the stage to one-on-one interacting with the students.

\section{Method:}

\subsection{Participants and location:}

The study was conducted at the King, Marriott Higher Institute for Computer Science, Alexandria, Egypt during the first semester of the academic year 2016-2017. 60 students (30 control group and 30 experimental group) participated in the study.

\subsection{Treatment:}

Two units from "Commercial\&Technical English Terminology Textbook"were used in this study (Unit 1: Introduction into Business English and Unit 2: Recruitment). The control group studied the two units through the regular nonflipped classroom. The experimental group studied the units through implementing CALL programs to flip the classroom. The researchers introduced the proposed CALL programs and how to use them during the introductory session.

\subsection{Instruments:}

\subsubsection{Achievement Test}

The researchers conducted an achievement test to assess the participants' performance. The test is composed of three parts; the first evaluates communication skills, the second assesses vocabulary acquisition and the third is reading comprehension. (Appendix I). 


\subsubsection{Attitude Survey:}

To assess the participants' attitudes toward the flipping classrooms in English language learning, the researchers conducted an attitude survey (appendix II). The researchers followed Lickert's 5 range scale in conducting the survey.

\section{Results:}

\subsection{Achievement hypothesis One}

There is a statistically significant difference between the mean scores of the experimental group students and that of the control group in the post application the achievement test in favor of the experimental group students.

To verify the validity of the previous hypothesis independent samples t-test was used. Table (1) shows the significance of difference between the mean scores of the control and the experimental group students in post-testing.

* This book is compiled and supplemented by one of the researchers (Dr. Ayman Elesery).

Table 1 :Significance of difference between the mean scores of the experimental and the control group students in post- testing

\begin{tabular}{|c|c|c|c|c|c|c|c|}
\hline Group & Mean & $\begin{array}{c}\text { Std. } \\
\text { Deviation }\end{array}$ & \multicolumn{2}{|c|}{$\begin{array}{c}\text { Levene's } \\
\text { Test }\end{array}$} & df & t & Sig. \\
\hline Control & 13.4 & 1.79 & F & Sig. & \multirow{2}{*}{58} & 5.35 & .001 \\
\hline Experimental & 15.7 & 1.57 & .31 & .57 & & & \\
\hline
\end{tabular}

The data presented in table (1) reveals that Levene's Test "F" (Equality of Variances) equals 0.31 which is significant at 0.57, " $t$ " value is (5.35) and significant at 0.001 , and "df" equals 58 which means that there is a statistically significant difference between the mean scores of the control and experimental group in post-testing.

\subsection{Attitudes:}

Hypothesis two: Participants have positive attitudes toward flipped classrooms in English language learning.

Results of attitude survey are presented in the following table. 
Table 2:Students' attitudes toward flipping the classrooms in English language learning

\begin{tabular}{|c|c|c|c|c|c|}
\hline Statement & $\begin{array}{c}\text { Strongly } \\
\text { agree }\end{array}$ & Agree & Indecisive & Disagree & \begin{tabular}{|l|} 
Strongly \\
disagree
\end{tabular} \\
\hline $\begin{array}{c}\text { 1. The flipped strategy } \\
\text { helped me to study } \\
\text { individually according } \\
\text { to my pace. }\end{array}$ & $\begin{array}{c}\text { No.12 } \\
(41.4 \%)\end{array}$ & $\begin{array}{c}\text { No.13 } \\
(44.8 \%)\end{array}$ & $\begin{array}{c}\text { No.3 } \\
(10.3 \%)\end{array}$ & $\begin{array}{c}\text { No.1 } \\
(3.4 \%)\end{array}$ & $\begin{array}{l}\text { No.0 } \\
(0 \%)\end{array}$ \\
\hline $\begin{array}{c}\text { 2. The flipped } \\
\text { strategy attracted me } \\
\text { to study more outside } \\
\text { the classroom. }\end{array}$ & $\begin{array}{c}\text { No.11 } \\
(36.7 \%)\end{array}$ & $\begin{array}{c}\text { No.14 } \\
(46.7 \%)\end{array}$ & $\begin{array}{c}\text { No.3 } \\
(10 \%)\end{array}$ & $\begin{array}{c}\text { No.2 } \\
(6.7 \%)\end{array}$ & $\begin{array}{l}\text { No.0 } \\
(0 \%)\end{array}$ \\
\hline $\begin{array}{c}\text { 3. The flipped } \\
\text { strategy helped me } \\
\text { to get more } \\
\text { knowledge and } \\
\text { information. } \\
\end{array}$ & $\begin{array}{l}\text { No.9 } \\
(30 \%)\end{array}$ & $\begin{array}{l}\text { No.15 } \\
\text { (50\%) }\end{array}$ & $\begin{array}{c}\text { No.5 } \\
(16.7 \%)\end{array}$ & $\begin{array}{c}\text { No.1 } \\
(3.3 \%)\end{array}$ & $\begin{array}{l}\text { No.0 } \\
(0 \%)\end{array}$ \\
\hline $\begin{array}{c}\text { 4. In-class activities } \\
\text { enhanced what I } \\
\text { studied outside the } \\
\text { classroom. } \\
\end{array}$ & $\begin{array}{c}\text { No.9 } \\
(30 \%)\end{array}$ & $\begin{array}{c}\text { No.16 } \\
(53.3 \%)\end{array}$ & $\begin{array}{c}\text { No.5 } \\
(16.7 \%)\end{array}$ & $\begin{array}{l}\text { No.0 } \\
(0 \%)\end{array}$ & $\begin{array}{l}\text { No.0 } \\
(0 \%)\end{array}$ \\
\hline $\begin{array}{c}\text { 5. In class activities } \\
\text { make the teacher } \\
\text { available to answer } \\
\text { questions. } \\
\end{array}$ & $\begin{array}{l}\text { No.18 } \\
(60 \%)\end{array}$ & $\begin{array}{c}\text { No.11 } \\
(36.7 \%)\end{array}$ & No.0 (0\%) & \begin{tabular}{|c|} 
No.1 \\
$(3.3 \%)$
\end{tabular} & $\begin{array}{l}\text { No.0 } \\
(0 \%)\end{array}$ \\
\hline $\begin{array}{c}\text { 6. Working with } \\
\text { colleagues } \\
\text { collaboratively in } \\
\text { class makes me more } \\
\text { active. }\end{array}$ & $\begin{array}{c}\text { No.9 } \\
(30 \%)\end{array}$ & $\begin{array}{c}\text { No.16 } \\
(53.3 \%)\end{array}$ & $\begin{array}{c}\text { No.4 } \\
(13.3 \%)\end{array}$ & $\begin{array}{c}\text { No.1 } \\
(3.3 \%)\end{array}$ & $\begin{array}{l}\text { No.0 } \\
(0 \%)\end{array}$ \\
\hline
\end{tabular}

Close inspection of the data presented in the previous table reveals that the participants have positive attitudes toward flipping the classrooms in English language learning.

\section{Discussion:}

The researchers implemented different CALL programs in this study like Natural Reader, Corpus concordancing, online listening $\mathrm{Lab}$ and PowerPoint presentations. The selected training units were explained and presented through PowerPoint program and were given to the experimental group students to be studied outside the classroom. Also, the experimental group students were trained during the introductory session on a cocordancing program for enhancing vocabulary acquisition and the natural reader program for developing reading skills. 
Experimental group students were trained to study the proposed units outside the classroom and to practice different activities in the classroom to enhance what they have studied. On the other hand the control group students studied with the regular method, i.e. explanation in the classroom and activities outside the classroom.

After finishing the treatment (2 units) both the experimental and the control group students sat for an achievement test and the experimental group students completed an attitude survey related to the flipped classrooms. The mean scores of the control and the experimental group were 13.4 and 15.7. The results of the achievement test highlights the effectiveness of flipping the classrooms. Furthermore, the results of the survey proved that experimental group students agreed upon flipping the classrooms.

\section{References:}

Beatty, K. (2003). Teaching and researching computer-assisted language learning. New York: Longman.

Bergmann, J., Overmyer, J., and Willie, B. (2011). The flipped class: What it is and What it is not. The Daily Riff. Retrieved from http://www.thedailyriff.com/ articles/the-flippedclass-conversation-689.php.

Centre for Academic Development and Quality

(2016). CADQ Guide: The flipped classroom. Nottingham Trent University. Retrieved from www.ntu.ac.uk/cadq

Davies, G., Hewer, S., Rendall, H., \& Walker, R. (2004). ICT4LT Module 1.4: Introduction to computer assisted language learning (CALL). http://www. ict4lt.org/en/en_mod14.html.

Han, W. (2008). Benefits and barriers of computer assisted language learning and teaching. US-China Foreign Language, 6(9), 40-43.

Levy, M. (1997) CALL: Context and conceptualization. Oxford: Oxford University Press. 
Levy, M. and Hubbard, P. (2005). Why call CALL ",'CALL"'? Computer Assisted Language Learning. Vol. 18, No. 3.

Li-Yun Lu and Tang, F (1996). Computer-Assisted Language Learning. NYU -School of Education - Department of Teaching and Learning-Multilingual Multicultural Studies TESOL.

Reinders, H., Thomas, M. (2012). Contemporary computer assisted language learning. Retrieved from http://www.eblib.com.

Tucker, B. (2012). The Flipped Classroom. Education Next. Retrieved from www. educationnext.org.

Warschauer M. (1996) "Computer Assisted Language Learning: an Introduction". In Fotos S. (ed.) Multimedia language teaching, Tokyo: Logos International: 3-20.

Warschauer, M., \& Healey, D. 1998. Computers and language learning: an overview. Language teaching forum. 31, Pp.5771. 
